\title{
LANDASAN FILOSOFIS PENGATURAN PASAR MODAL DI INDONESIA: HARAPAN DAN KENYATAAN
}

\author{
Marihot Janpieter $\mathbf{H}$. \\ Staf Pengajar Fakultas Hukum Universitas Kristen Satya Wacana \\ Korespondensi: marihotjanpieter@gmail.com
}

\begin{abstract}
Abstrak
Keberadaan pasar modal di Indonesia dibutuhkan mengingat peranannya yang penting untuk menyokong kondisi perekonomian negara. Namun pasar modal sebagai lembaga yang berasal dari sistem ekonomi liberal-kapitalistik tidak serta merta dapat dengan mudah diadopsi dan diatur tanpa disesuaikan dengan filosofi bangsa Indonesia. Melalui tulisan ini, Penulis hendak menganalisis kesesuaian tujuan pengaturan dan pengembangan pasar modal di Indonesia dengan konsep Negara Kesejahteraan Indonesia pasca Amandemen Undang-Undang Dasar Negara Republik Indonesia Tahun 1945. Analisis tulisan ini menyimpulkan bahwa tujuan pengembangan pasar modal Indonesia adalah mewujudkan masyarakat yang adil dan makmur, namun tujuan pengaturan pasar modal itu sendiri belum sesuai dengan konsep negara kesejahteraan Indonesia serta belum memenuhi harapan konstitusional bangsa ini.
\end{abstract}

Kata-kata Kunci: Filsafat Hukum; Pengaturan; Pasar Modal.

\begin{abstract}
In Indonesia the existence of capital market is needed considering the important role to support the country's economy. But the capital market as an institution derived from the liberal-capitalistic economic system can not necessarily be adopted and arranged without adjustment to the philosophy of the Indonesian nation. Through this article, the author analyzes the suitability of regulation and development of capital markets in Indonesia with the concept of Indonesian welfare state after the amendment to the Constitution of the Republic of Indonesia of 1945. The analysis of this paper draws a conclusion that the purpose of the Indonesian capital market development is to realize a just and prosperous society, but the goal of the capital market regulation itself is not in accordance with the concept of Indonesia as well as the concept of welfare state and thus has not met expectations of the nation's constitutional expectations.
\end{abstract}

Key Words: Philosophy of Law; Regulation; Capital Markets. 


\section{PENDAHULUAN}

Walaupun pasar modal telah berkembang cukup pesat di Indonesia, namun demikian ternyata masih ada pendapat pro dan kontra atas pengembangan pasar modal di Indonesia. Beberapa kalangan masih ada yang tidak setuju dengan adanya pasar modal, sebab mereka berpendapat bahwa pasar modal merupakan suatu produk asing yang berasal dari sistem ekonomi kapitalis dan tidak cocok untuk diterapkan di Indonesia.

Pada dasarnya pengaturan pasar modal nasional bertujuan untuk mewujudkan masyarakat adil dan makmur. Hal itu dieksplisitkan dalam konsiderans huruf a Undang-Undang Nomor 8 Tahun 1995 tentang Pasar Modal (UU Pasar Modal). Dalam praktiknya, meskipun tujuan pengaturan diharapkan dapat menjadi pendorong terwujudnya masyarakat adil dan makmur, namun dalam pengaturan pasar modal tersebut belum benar-benar tercermin bahwa pasar modal dapat memberi wadah bagi seluruh kalangan masyarakat Indonesia. Selain hal tersebut, dapat dilihat bahwa meskipun pasar modal dapat dinikmati untuk seluruh kalangan masyarakat, namun dalam pengaturannya tidak ditemukan aturan yang benar-benar mewadahi pasar modal bagi masyarakat pemodal kecil.

Dalam pelaksanaan pengaturan pasar modal Indonesia, dalam kaitannya dengan landasan filosofis dan dasar pengaturannya seharusnya diarahkan untuk mewujudkan asas atau prinsip- prinsip yang terdapat dalam Pasal 33 Undang-Undang Dasar Negara Republik Indonesia Tahun 1945 (UUD NRI 1945), seperti asas kekeluargaan, serta pemberdayaan koperasi dan usaha menengah kecil dan mikro (selanjutnya ditulis UMKM). Hal tersebut dikarenakan hingga saat ini dalam praktik tidak ditemukan adanya pengakomodasian lembaga koperasi dan UMKM di dalam pasar modal. Dalam kenyataannya pasar modal lebih banyak dimanfaatkan oleh perusahaan swasta nasional dan asing, baik sebagai emiten maupun investor di pasar modal.

Tulisan ini mengangkat persoalan landasan filosofis pengaturan pasar modal di Indonesia dengan meninjau arah pengaturan dan pengembangan pasar modal di Indonesia dan kesesuaiannya dengan dasar negara dan landasan filosofis bangsa Indonesia, terutama setelah UUD NRI 1945 mengalami 4 kali amandemen. Berdasarkan latar belakang tersebut dirumuskan masalah-masalah sebagai berikut. Pertama, apakah tujuan pengembangan pasar modal Indonesia berbeda dengan pasar modal di negara yang menganut sistem ekonomi kapitalistik? Kedua, apakah tujuan pengaturan pasar modal Indonesia sudah bersesuaian dengan konsep Negara Kesejahteraan Indonesia? Ketiga, bagaimana filosofi/tujuan pengaturan pasar modal Indonesia ditinjau dari Pasal 33 UUD 1945 Pasca Amandemen? 


\section{PEMBAHASAN}

\section{Pasar Modal dalam Sistem Ekonomi Negara Kapitalistik}

Kapitalisme sebagai praktik ekonomi dan sistem sosial ditandai oleh adanya kelas, yaitu kelas kapitalis dan kelas proletar. ${ }^{1}$ Ideologi yang melatarbelakangi kapitalisme adalah liberalisme yang mengandung 3 unsur, yaitu: lembaga milik pribadi, pencarian untung dan kompetisi dalam pasar bebas. ${ }^{2}$

Negara-negara kapitalis dalam memaknai pembangunan ekonomi dan kesejahteraan sosial tidak memandangnya sebagai 2 "sektor" yang berlainan dan berlawanan. ${ }^{3}$ Umer Chapra menyebutkan 5 ciri kapitalisme sebagai berikut:

1. Percaya bahwa ekspansi kekayaan dapat dipercepat, produksi maksimum dan pemuasan keinginan sesuai dengan preferensi individu sangat penting bagi kesejahteraan;

2. Kebebasan individu tanpa batas untuk menciptakan kekayaan pribadi, memiliki dan mengaturnya sebagai keharusan bagi inisiatif individu;

3. Inisiatif individu dan pengambilan keputusan dalam pasar bebas sebagai syarat efisiensi optimum alokasi sumber daya;
4. Tidak perlu peran pemerintah dan nilai-nilai kolektif dalam efisiensi alokasi dan keadilan distribusi;

5. Pemenuhan kepentingan pribadi oleh semua individu secara otomatis akan memenuhi kepentingan sosial. ${ }^{4}$

Sistem ekonomi kapitalis menghendaki atas adanya pertumbuhan ekonomi secara besar-besaran agar dapat memenuhi kebutuhan masyarakatnya, dengan begitu kebijakan yang berkembang dalam negara kapitalis adalah mengutamakan adanya investasi secara besar-besaran baik dari modal domestik maupun modal asing. ${ }^{5}$ Walau sistem ekonomi kapitalis menghendaki adanya pemenuhan kepentingan masyarakat namun dalam teknisnya pemerintah tidak mencampuri secara langsung melainkan menyerahkannya langsung kepada pasar. ${ }^{6}$

\section{Pasar Modal di Indonesia}

Jika dilihat dari prinsip-prinsip yang digunakan di negara kapitalis, maka dapat dipahami bahwa dalam kegiatan pasar modal juga menggunakan prinsip yang sama. Tidak adanya campur tangan dari pemerintah dalam bidang perekonomian warganya menjadi hal yang berbeda dengan sistem ekonomi yang dianut oleh Indonesia.

K. Bertens, Pengantar Etika Bisnis (Kanisius 2000) 135.

Ibid.

Edi Suharto, 'Globalisasi, Kapitalisme, dan Negara Kesejahteraan: Mengkaji Peran Negara Dalam Pembangunan Kesejahteraan Sosial di Indonesia' <http://www.policy.hu/suharto/modul_a/ makindo_08.htm> diakses 19 Mei 2014.

Indah Piliyanti, 'Menggugat Sistem Kapitalisme' (2009) 3 Jurnal Ekonomi Islam 46, 50.

Jimly Asshiddiqie, Konstitusi Ekonomi (Kompas 2010) 343.

Ibid. 
Arief Budiman mengajukan pertanyaan mengenai asumsi konsep manusia dalam Ekonomi Pancasila yang sudah jelas dalam teori ekonomi kapitalis, yaitu homo-economicus yang serakah, dan dalam teori sosialis juga jelas, yaitu homo-socius yang cenderung melakukan kerjasama dan mengutamakan masyarakat. Pada waktu itupun sudah diberikan jawaban bahwa konsep manusia dalam Ekonomi Pancasila, lebih merupakan homo-socius dan homo-ethicus atau homo-religious. ${ }^{7}$

Modal merupakan salah satu faktor penting dalam pembangunan ekonomi, yang antara lain dapat diperoleh di pasar modal, yang pasar modal sebagai salah satu sarana sumber pembiayaan maupun berinvestasi. ${ }^{8}$ Sesuai penjelasan tersebut dapat diketahui bahwa pasar modal tidak dapat dipisahkan dari kegiatan ekonomi suatu negara. Pasar modal menjadi lembaga yang menjembatani antara pengguna dana dengan pemilik dana (investor) untuk tujuan investasi, baik jangka menengah maupun jangka panjang. ${ }^{9}$

UU Pasar Modal merupakan salah satu produk hukum di bidang perekonomian yang dibutuhkan perannya untuk menggantikan ketentuan-ketentuan lama (seperti ketentuan Kitab UndangUndang Hukum Dagang - KUHD tentang Bursa Perniagaan dan Undang-
Undang Nomor 15 Tahun 1952 tentang Bursa) yang sudah usang karena tidak sesuai lagi dengan perkembangan yang ada, sejalan dengan hasil-hasil yang dicapai dalam pembangunan nasional serta dalam rangka antisipasi atas globalisasi ekonomi. ${ }^{10}$ UU Pasar Modal menjabarkan makna dari pasar modal dalam Pasal 1 Angka 13 yang menyebutkan bahwa Pasar Modal merupakan kegiatan yang bersangkutan dengan Penawaran Umum dan perdagangan Efek, Perusahaan Publik yang berkaitan dengan Efek yang diterbitkannya, serta lembaga dan profesi yang berkaitan dengan Efek.

\section{Konsep Negara Kesejahteraan Indonesia}

Konsep negara kesejahteraan di Indonesia pertama kali muncul di dalam sidang BPUPKI. Gagasan tersebut muncul berkaitan dengan prinsipprinsip dasar negara kelak saat Indonesia merdeka. Dasar pemikiran negara kesejahteraan tersebut berisi 4 prinsip yang dikemukakan oleh Bung Karno meliputi:

1. Kebangsaan lndonesia;

2. Internasionalisme, atau perikemanusiaan,

3. Mufakat, atau demokrasi;

4. Kesejahteraan sosial.

7 Dawam Rahardjo, 'Ekonomi Pancasila Dalam Tinjauan Filsafat Ilmu', <http:// www.ekonomikerakyatan.ugm.ac.id/My\%20Web/sembul12_2.htm> diakses 18 Mei 2014.

$8 \quad$ Lastuti Abubakar, Transaksi Derivatif Di Indonesia: Tinjauan Hukum tentang Perdagangan Derivatif di Bursa Efek (Book Terrace \& Library 2009) 46.

9 Jusuf Anwar, Penegakan Hukum dan Pengawasan Pasar Modal Indonesia, (PT Alumni 2008) 121. Pengertian Pasar Modal sebagi wadah yang mempertemukan investor dan emiten tersebut juga dapat dilihat dalam M. Irsan Nasarudin, Aspek Hukum Pasar Modal Indonesia (Kencana 2004) 10 .

10 Konsiderans huruf d UU Pasar Modal. 
Kemudian pemikiran prinsip ke-5: lndonesia Merdeka dengan bertaqwa kepada Tuhan Yang Maha Esa. Pemikiran pada saat itu adalah bahwa kesejahteraan sosial bertujuan untuk menghapuskan kemiskinan dari seluruh bangsa Indonesia. Prinsip-prinsip yang dijabarkan oleh Bung Karno tersebut tertuang dalam pembukaan UndangUndang Dasar Republik Negara Indonesia Tahun 1945 dan dalam Bab XIV Tentang Kesejahteraan Sosial. ${ }^{11}$

Terkait dengan negara kesejahteraan sosial, Mahfudz menegaskan bahwa pada saat pembentukan prinsip negara Indonesia, ternyata Bung Karno mengadopsi 2 faham negara hukum sekaligus (faham negara hukum formal/ negara penjaga malam/ nachtwachterstaaf dan faham negara hukum material/negara kesejahteraan/ anlwelfare staie). Negara berperan aktif untuk membangun kesejahteraan sosial yang lebih bersifat organistik samasama terdapat di dalam pandangan dan sikapnya. ${ }^{12}$

Mohammad Hatta kemudian memunculkan pemikiran tentang Pasal 33 UUD NRI 1945 beserta Penjelasannya (sebelum diamandemen) sebagai bentuk demokrasi sosial, yang mencakup demokrasi politik dan demokrasi ekonomi, yang keadilan sosial menjadi tujuan utama. Kedaulatan rakyat lndonesia tidak terlepas dari tujuan inheren-nya, yaitu keadilan bagi seluruh rakyat (keadilan sosial). ${ }^{13}$

Keadilan dan ekonomi merupakan hal yang selalu terkait, seperti yang dapat dilihat dalam rumusan yang ada di Indonesia yaitu "masyarakat yang adil dan makmur". ${ }^{14}$ Hal ini sebagaimana pendapat Mohammad Hatta yang menyebutkan tentang makna adil dan makmur yang tidak dapat dipisahkan satu dan lainya. Kesejahteraan Sosial Ekonomi dalam hal ini merupakan aspek penting dalam konsep Negara Kesejahteraan.

Jika negara kapitalis menganggap kemiskinan dan perekonomian pada umumnya merupakan urusan pasar, dan karena itu tidak perlu diurus oleh negara (pemerintah), maka dalam konsep "negara pengurus" (welfare stafe), pada intinya negara memang diharapkan turut bertanggung jawab untuk mengintervensi pasar, mengurus kemiskinan, dan memelihara orang miskin. ltulah sebabnya maka di dalam UUD NRI 1945 dirumuskan satu bab tersendiri tentang Kesejahteraan Sosial yang berisi 2 pasal, yaitu Pasal 33 dan $34 .{ }^{15}$

Negara kesejahteraan dalam bidang ekonomi mengatur kebijakan ekonomi yang diarahkan untuk mewujudkan untuk peningkatan kesejahteraan sebagian besar orang, pertumbuhan dan

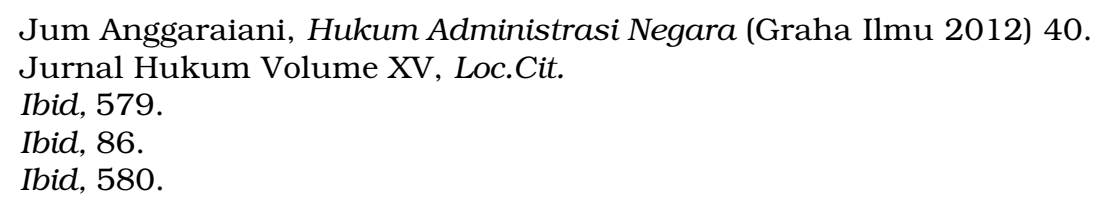


pemerataan serta kemakmuran dan keadilan sosial. ${ }^{16}$ Dalam konsep negara kesejahteraan, negara diharapkan turut bertanggung jawab untuk mengintervensi pasar, mengurus kemiskinan, dan memelihara orang miskin. Kesejahteraan sosial di Indonesia diharapkan terwujud dengan berdasarkan pada suatu usaha dalam bidang perekonomian, yang dibangun dan dikembangkan dengan prinsip kekeluargaan, guna memenuhi kebutuhan bersama (seluruh masyarakat Indonesia), yang akhirnya diharapkan mampu mewujudkan masyarakat adil dan makmur.

Sistem Ekonomi Indonesia Menurut Pancasila dan Pasal 33 UUD NRI 1945 Paska Amandemen

Peradaban ekonomi Indonesia yang dibangun atas asas Pancasila pada dasarnya dilandaskan pada keadilan dalam ekonomi. ${ }^{17}$ Di antara 5 sila, sila keadilan sosial bagi seluruh rakyat Indonesia, sila kemanusiaan yang adil dan beradab, dan sila Ketuhanan Yang Maha Esa adalah 3 sila yang sifatnya paling asasi. ${ }^{18}$ Dari 3 sila tersebut kemudian muncul ungkapan "masyarakat yang adil dan makmur", yang merupakan 2 pengertian yang saling melengkapi satu sama lain, dan bersama-sama mensyaratkan kehidupan masyarakat Indonesia yang baik. ${ }^{19}$ Makna dalam "Keadilan Sosial bagi Seluruh Rakyat Indonesia" secara filsafati yang terkandung dalam frasa tersebut jelas merupakan tujuan yang harus dicapai, serta untuk mengukur keberhasilan atau kegagalan kinerja seluruh aparatur penyelenggara negara. ${ }^{20}$

Pada masa paska reformasi, dalam penjelasan UUD NRI 1945 maupun Pasal 33 UUD NRI 1945 mengandung gagasan tentang demokrasi ekonomi, yang artinya adalah pemegang kekuasaan tertinggi di tangan rakyat. ${ }^{21}$ Dalam konteks bernegara, kedaulatan rakyat bersifat mutlak, meskipun dibatasi oleh ke-maha-kuasaan Tuhan dalam alinea ke-3 pembukaan UUD NRI Tahun 1945. ${ }^{22}$ Bagi lndonesia, gagasan kedaulatan yang kemudian menjadi muatan UUD NRI Tahun 1945 memang terkait dengan pemikiran khas lndonesia.

Dalam konsep kedaulatan rakyat Indonesia, manusia diberi kekuasaan untuk mengolah dan mengelola alam dan digunakan sebesar-besarnya demi kemakmuran bersama berdasarkan atas demokrasi ekonomi dengan prinsip kebersamaan, efesiensi-berkeadilan, berkelanjutan, berwawasan lingkungan, kemandirian, serta dengan menjaga

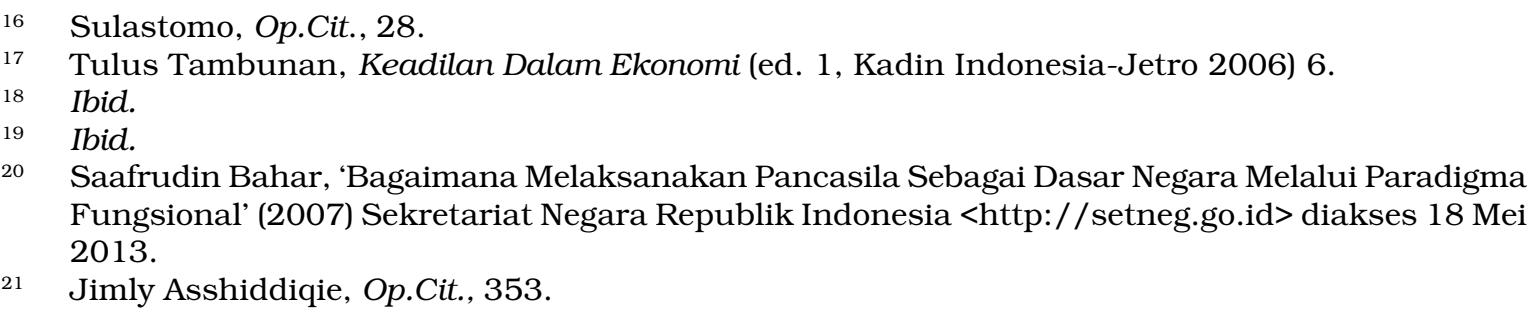
Fungsional’ (2007) Sekretariat Negara Republik Indonesia <http://setneg.go.id> diakses 18 Mei 2013.

21 Jimly Asshiddiqie, Op.Cit., 353.

22 Ibid. 
keseimbangan kemajuan dan kesatuan ekonomi nasional. ${ }^{23}$

Kesempatan bagi masyarakat pemodal kecil dalam mendorong iklim investasi di Indonesia, serta turut serta dalam menggerakkan industri pasar modal hal tersebut pada akhirnya menjadi suatu perwujudan dari landasan filosofis pasar modal Indonesia yaitu Pancasila. Perwujudan asas kekeluargaan ini, sejalan dengan Sila ke5 Pancasila yang menekankan pada pokok keadilan sosial bagi seluruh rakyat Indonesia.

Berdasarkan uraian di atas, adanya perwujudan dari asas kekeluargaan dalam Pasal 33 Ayat (1) UUD NRI Tahun 1945, serta perwujudan atas Sila ke-5 Pancasila, maka dalam hal ini masyarakat kecil pada akhirnya memiliki andil dalam pembangunan ekonomi Indonesia. Peran dalam masyarakat pemodal dalam hal ini merupakan perwujudan prinsip kepentingan publik maupun kepentingan sosial sesuai dengan klasifikasi dalam social interest yang dikemukakan oleh Roscou Pound dalam teori social enginering. ${ }^{24}$

Pengaturan yang berkaitan dengan perekonomian Indonesia tertuang dalam Bab XIV UUD NRI Tahun 1945 Tentang Perekonomian Nasional dan Kesejahteraan Sosial, yang salah satunya dituangkan dalam Pasal 33 setelah Amandemen. Pasal 33 ayat (1)
UUD NRI 1945 harus menjadi landasan konstitusional dalam membangun perekonomian Indonesia. Dalam makna luas, "kekeluargaan" disini dimaksudkan bahwa untuk membangun perekonomian Indonesia dilakukan secara bersama-sama oleh masyarakat Indonesia. ${ }^{25}$

Pasal 33 Ayat (1) UUD NRI 1945 menyebutkan bahwa perekonomian Indonesia disusun sebagai usaha bersama berdasarkan atas asas kekeluargaan. Asas kekeluargaan yang mendasari setiap kegiatan perekonomian nasional terlihat dalam penjabaran Pasal 33 Ayat (1) UUD NRI Tahun 1945 yang menyebutkan bahwa perekonomian disusun sebagai usaha bersama berdasar asas kekeluargaan. Makna usaha bersama dalam hal ini merupakan pandangan terhadap 3 segi kegiatan usaha di Indonesia, yaitu: pengertian dalam arti mikro, pengertian dalam arti makro, dan usaha bersama sebagai prinsip atau jiwa. ${ }^{26}$

Selain dalam Pasal 33 ayat (1) UUD NRI 1945, prinsip perekonomian Indonesia juga dapat dilihat dalam Pasal 33 ayat (4) UUD NRI 1945. Ditegaskan bahwa perekonomian diselenggarakan berdasarkan pada demokrasi ekonomi. Pelaksanaan dalam demokrasi ekonomi berdasarkan prinsip-prinsip yang telah disebutkan dalam pasal dan ayat yang sama, yaitu: prinsip kebersamaan, efisiensi berkeadilan, berkelanjutan,

\footnotetext{
23 Jimly Asshidiqie, Op.Cit. 353.

24 Benard L. Tanya (et.al), Teori Hukum: Strategi Tertib Manusia Lintas Ruang dan Generasi (Genta Publishing 2010) 155.

25 Ibid, 270.

26 Jimly Asshidiqie., Op.Cit, 269.
} 
berwawasan lingkungan, kemandirian, serta dengan menjaga keseimbangan kemajuan dan kesatuan ekonomi nasional.

\section{Tujuan Pengembangan Pasar Modal Indonesia dalam Pembangunan Ekonomi Nasional Indonesia}

Melihat pada kondisi pada saat pengaturan pembangunan jangka panjang Indonesia masih dalam GBHN tentu berbeda dengan kondisi sekarang, saat pembangunan nasional mulai dirumuskan dalam Undang-Undang No 17 Tahun 2007 tentang Rencana Pembangunan Jangka Panjang Nasional 2005-2025 dan Peraturan Presiden Nomor 5 Tahun 2010 tentang Rencana Jangka Menengah Nasional. Saat ini pasar modal memiliki peran penting dalam sektor keuangan, pasar modal memberi dukungan bagi dunia usaha dengan memperkokoh struktur permodalan sehingga dunia usaha dapat mengatur kombinasi sumber pembiayaannya yang mencerminkan perpaduan sumber pembiayaan jangka panjang. ${ }^{27}$ Selain dalam RPJPN dan RJMN, kebijakan tentang pengembangan pasar modal oleh Bapepam dan LK dijabarkan dalam Master Plan Pasar Modal dan Lembaga Keuangan Non-Bank 2009-2014.

Kebijakan dalam pasar modal diarahkan dalam perkembangan ekonomi Indonesia ke depan akan diwarnai dengan upaya pemulihan ekonomi dan persiapan guna menuju era perdagangan bebas. ${ }^{28}$ Dalam master plan pasar modal dan industri keuangan non bank 2010-2014 pasar modal Indonesia memiliki visi untuk menjadi otoritas lembaga keuangan yang amanah dan profesional, yang mampu mewujudkan industri pasar modal dan lembaga keuangan non bank sebagai penggerak perekonomian nasional yang tangguh dan berdaya saing global. Pasar modal juga memiliki misi untuk menciptakan iklim yang kondusif bagi perusahaan dalam memperoleh pembiayaan dan bagi pemodal dalam memilih alternatif investasi pada industri pasar modal dan jasa keuangan non bank.

Pada masa kerja periode 2005-2009 kinerja pasar modal Indonesia mengalami tren pertumbuhan yang meningkat, kecuali pada tahun 2008 yang sempat menurun dikarenakan pengaruh akibat krisis global pada pertengahan tahun 2008. ${ }^{29}$ Tren perkembangan tersebut juga terjadi dalam aliran modal asing ke dalam pasar modal Indonesia. ${ }^{30}$ Untuk mewujudkan visi-misi dalam master plan Bapepam dan LK tahun 2010-2014 telah ditetapkan 5 tujuan utama yang akan dicapai dalam 5 tahun ke depan, yang tujuan tersebut selanjutnya akan dijabarkan dalam strategi dan programprogram dalam suatu rencana aksi yang terencana dan terukur. ${ }^{31}$

\footnotetext{
27 Tavinayati dan Yulia Gamariyanti, Hukum Pasar Modal Indonesia (Sinar Grafika 2009) 6.

28 Lastuti Abubakar, Op.Cit., 53.

29 Bapepam dan LK (2), Op.Cit, Bab Gambaran Umum, sub Bab kinerja Pasar Modal

30 Ibid.

$31 \quad$ Ibid, 12 .
} 
Dalam perkembangannya dengan perkembangan ekonomi suatu negara, fungsi pasar modal dapat dijabarkan sebagai berikut: ${ }^{32}$

1. Sarana menghimpun permodalan dari dana masyarakat;

2. Sumber pembiayaan yang mudah, murah, dan cepat bagi dunia usaha dan pembangunan nasional;

3. Mendorong terciptanya kesempatan berusaha sekaligus menciptakan kesempatan kerja;

4. Mempertinggi alokasi sumber produksi;

5. Memperkokoh mekanisme financial market dalam menata sistem moneter;

6. Menekan bunga menuju rate yang reasonable;

7. Sebagai alternatif investasi bagi pemodal.

Visi dalam pembangunan nasional dalam Undang-Undang No 17 Tahun 2007 merupakan landasan bagi pembangunan nasional Indonesia dalam jangka 2005-2025. Lampiran UndangUndang No 17 Tahun 2007 memuat visimisi pembangunan nasional 2005-2025. Visi pembangunan ekonomi Indonesia adalah "Indonesia yang Mandiri, Maju, Adil, dan Makmur". ${ }^{33}$

Lampiran Undang-Undang No 17 Tahun 2007 menjelaskan bahwa kemandirian suatu bangsa termasuk tercermin dari kemampuannya dalam memenuhi tuntutan kebutuhan dan kemajuan pembangunannya yang tidak bergantung pada sumber pembiayaan dari luar negeri. Sedangkan Peraturan Presiden Nomor 5 Tahun 2010 menjelaskan bahwa yang dimaksud dengan kemandirian adalah kemampuan untuk mewujudkan kehidupan yang sejajar dan sederajat dengan bangsa lain yang lebih maju dengan berdasar pada kekuatan sendiri. ${ }^{34}$ Pengertian tersebut sejalan dengan lampiran Undang-Undang No 17 Tahun 2007 yang menjelaskan bahwa kemandirian merupakan hakikat dari kemerdekaan, yaitu hak setiap bangsa untuk menentukan nasibnya sendiri dan menentukan apa yang terbaik bagi bangsanya. ${ }^{35}$

Saat ini kemandirian ekonomi nasional telah menjadi tuntutan riil. Ketergantungan pada keterdiktean oleh pihak luar negeri digugat sebagai penyelewengan mendasar dari cita-cita kemerdekaan nasional, sekaligus memperpuruk martabat, prestise dan harga diri bangsa. Keinginan untuk mewujudkan kemandirian terlihat dalam angka 5.2.4 Peraturan Presiden Nomor 5 Tahun 2010 yang menyatakan tentang Kebutuhan Investasi dan Kebijakan pendanaan Pembangunan Nasional serta Pemanfaatannya. Dalam poin tersebut dijelaskan bahwa untuk mencapai sasaran pembangunan, kebijakan pendanaan investasi

\footnotetext{
Ibid, 7.

Bab III Lampiran Undang-Undang No 17 Tahun 2007 tentang Rencana Pembangunan Jangka Panjang Nasional 2005-2025.

34 Peraturan Presiden Nomor 5 Tahun 2010 Tentang Rencana Jangka Menengah Nasional, 1-22.
}

35 Ibid. 
diarahkan untuk menjamin ketersediaan dan mengoptimalkan pendanaan pembangunan menuju kemandirian pendanaan pembangunan yang disusun strategi utama pendanaan pembangunan adalah (i) optimalisasi sumber dan skema pendanaan pembangunan baik yang telah ada maupun yang akan dikembangkan, dan (ii) peningkatan kualitas pemanfaatan sumber dan skema pendanaan pembangunan.

Pasar modal memiliki keterkaitan dengan visi kemakmuran dalam Undang-Undang No 17 Tahun 2007. Dalam arah, tahapan, dan prioritas pembangunan jangka panjang tahun 2005-2025, untuk mewujudkan bangsa yang berdaya saing dilaksanakan dengan jalan memperkuat perekonomian domestik dengan orientasi dan berdaya saing global. Angka 14 lampiran tersebut, ${ }^{36}$ menjelaskan bahwa investasi diarahkan untuk mendukung terwujudnya pertumbuhan ekonomi yang cukup tinggi secara berkelanjutan dan berkualitas mewujudkan iklim investasi yang menarik termasuk dalam hal pengembangan investasi dalam rangka demokrasi ekonomi yang digunakan sebesar-besarnya untuk kemakmuran rakyat.
Selain dalam kepentingan terhadap pembangunan yang berkaitan langsung dengan masalah dalam negeri, dalam Undang-Undang No 17 Tahun 2007 Indonesia juga ditekankan dalam hal meningkatkan investasi perusahaanperusahaan asing ke Indonesia. ${ }^{37}$ Investasi di sini diperlukan sebagai langkah untuk meningkatkan tujuantujuan pembangunan Indonesia yang pada dasarnya faktor modal menjadi faktor penting dalam pembangunan ekonomi.

Menurut Aminudin Ilmar sebagai mana dikutip oleh Jonker Sihombing, salah satu fungsi penanaman modal sebagai salah satu alternatif untuk memecahkan kesulitan modal yang dibutuhkan dalam pelaksanaan pembangunan nasional. ${ }^{38}$ Modal sebagai suatu objek dari penanaman modal ini dapat berupa, baik uang maupun bentuk lain yang bukan uang yang dimiliki oleh penanam modal yang mempunyai nilai ekonomis. ${ }^{39}$

Dari uraian diatas terlihat bahwa di Indonesia, perekonomian pada umumnya dan khususnya di bidang pasar modal masih berada di bawah campur tangan pemerintah, yang dilakukan dengan cara menetapkan peraturan dan kebijakan-kebijakannya agar kegiatan yang dilaksanakan

36 Bab IV Huruf B Angka 14 Lampiran Undang-Undang Nomor 17 Tahun 2007 Tentang Rancangan Pembangunan Jangka Panjang Nasional.

37 Bab IV Huruf H angka 5 Undang-Undang Nomor 17 Tahun 2007 tentang Rancangan Pembangunan Jangka Panjang Nasional.

38 Jonker Sihombing, Peran dan Aspek Hukum dalam pembangunan Ekonomi (PT Alumni 2010) 118.

39 Pasal 1 Angka 7 Huruf a Undang-Undang Nomor 25 Tahun 2007 tentang Penanaman Modal. 
berjalan sesuai dengan apa yang menjadi tujuan dari Indonesia.

\section{Tujuan Pengaturan Pasar Modal di Indonesia Ditinjau dari Konsep Negara Kesejahteraan Indonesia}

Sebagai negara yang telah memiliki konsep negara kesejahteraan, maka Indonesia, dalam pengaturan di bidang ekonomi seharusnya memperhatikan adanya konsep tersebut. Khususnya dalam bidang pasar modal, pengaturannya harus disesuaikan dengan konsep negara kesejahteraan Indonesia, mengingat pasar modal diadopsi dari negara yang menganut sistim ekonomi kapitalistik.

Diketahui bahwa pasar modal Indonesia telah memiliki peraturan pokok yang diatur dalam UndangUndang Nomor 8 Tahun 1995 tentang Pasar Modal, yang sebelumnya telah diatur dalam Undang-Undang No. 15 Tahun 1952 tentang Bursa. UndangUndang No. 15 Tahun 1952 dalam pelaksanaannya dirasakan sudah tidak sesuai lagi dengan perkembangan yang ada pada saat itu. Pertama, ketentuan yang ada dalam undang-undang tersebut tidak mengatur hal-hal yang sangat penting dalam kegiatan Pasar Modal, yaitu kewajiban Pihak-Pihak dalam suatu Penawaran Umum untuk memenuhi Prinsip Keterbukaan (full disclosure), serta terutama ketentuanketentuan yang mengatur tentang perlindungan kepada masyarakat umum. Kedua, UU No. 15 Tahun 1952 tersebut belum mengakomodasi mengenai globalisasi ekonomi (economic globalization). Berdasarkan kedua faktor tersebut, dibentuklah UU No. 8 Tahun 1995 yang mengakomodasi mengenai prinsip keterbukaan (full and fair disclosure) dan globalisasi ekonomi (economic globalization).

Di awal disebutkan bahwa UU No. 15 Tahun 1952 tidak mengakomodir prinsip keterbukaan dan perlindungan terhadap investor (pemodal). UU Nomor 8 Tahun 1995, dalam pengaturannya telah mampu mengakomodir 2 prinsip tersebut. Prinsip keterbukaan atau yang sering disebut pula dengan transparansi dalam pasar modal merupakan terminologi yang sangat penting dan fundamental. ${ }^{40}$ Keterbukaan merupakan kewajiban emiten yang menawarkan efeknya melalui pasar modal untuk mengungkapkan seluruh informasi secara transparan tentang keadaan usahanya termasuk keadaan keuangan, aspek hukum, manajemen dan harta kekayaan perusahaan kepada masyarakat (pemodal). ${ }^{41}$

Strategi dan arah kebijakan pembangunan pasar modal di Indonesia diarahkan untuk mewujudkan pembangunan nasional di bidang ekonomi. Semangat yang dibangun dalam pembangunan pasar modal terutama adalah semangat mewujudkan prinsip keterbukaan (full and fair disclosure) dan merespon globalisasi ekonomi (economic globalization) ${ }^{42}$.

Ibid, 225.

41 Jusuf Anwar, Pasar Modal Sebagai Sarana Pembiayaan dan Investasi (Alumni 2010) 208.

42 Disarikan dari Penjelasan Umum atas UU No. 8 Tahun 1995 tentang Pasar Modal. 
Prinsip keterbukaan dalam UU Nomor 8 Tahun 1995 juga terlihat dalam Pasal 86 Ayat (1) yang menentukan bahwa emiten, perusahaan publik, atau pihak lain yang terkait wajib menyampaikan informasi penting yang berkaitan dengan tindakan atau efek perusahaan dalam waktu yang tepat kepada masyarakat dengan bentuk laporan berkala maupun laporan peristiwa penting. ${ }^{43}$ Pelanggaran terhadap prinsip keterbukaan dalam pasar modal dapat dikenakan sanksi, baik sanksi administratif maupun sanksi pidana oleh Bapepam dan LK, ${ }^{44}$ yang saat ini telah dialihkan kepada Otoritas Jasa Keuangan yang dibentuk berdasarkan UU Nomor 21 Tahun 2011 tentang Otoritas Jasa Keuangan.

Untuk prinsip perlindungan investor dalam pasar modal diatur di dalam Pasal 4 UU Nomor 8 Tahun 1995. Pasal tersebut mengatur bahwa Bapepam memiliki 2 fungsi; Pertama fungsi sebagai pembina, pengatur, dan pengawas pasar modal dengan tujuan mewujudkan pasar modal yang teratur, wajar, dan efisien dan yang kedua, melindungi kepentingan masyarakat dan pemodal. ${ }^{45}$

Dalam mewujudkan konsep negara kesejahteraan, pengaturan dalam pasar modal tidak hanya mengarah pada pihak-pihak yang terdapat di dalamnya, namun diharapkan mampu menjangkau dan mewujudkan tujuan pengaturan pasar modal dalam konsiderans huruf a UU Nomor 8 Tahun 1995. Ciri utama negara kesejahteraan adalah pemerintah memiliki kewajiban untuk mewujudkan kesejahteraan umum bagi warganya. ${ }^{46}$ Konsepsi negara hukum untuk mencapai negara kesejahteraan di Indonesia terkandung dalam alinea 4 Pembukaan UUD NRI Tahun 1945, yang tercermin dari tujuan dari negara Indonesia, yaitu dalam memajukan kesejahteraan umum, mencerdaskan kehidupan bangsa, dan seluruh tumpah darah Indonesia serta memajukan kesejahteraan umum, mencerdaskan kehidupan bangsa dan ikut melaksanakan ketertiban dunia yang berdasar perdamaian abadi dan keadilan sosial. $^{47}$

UU Nomor 8 Tahun 1995 telah meletakkan dasar bahwa pasar modal juga menjadi wadah investasi bagi masyarakat pemodal kecil dalam penjelasan bagian umum UU Pasar Modal. Namun, dalam pasal-pasal UU Nomor 8 Tahun 1995 tidak ada satupun yang menyatakan bahwa terdapat suatu wadah yang dapat digunakan oleh masyarakat pemodal kecil untuk berinvestasi. Indonesia yang menganut sistem negara kesejahteraan seharusnya dapat memberi pengaturan tentang pemberian kesempatan bagi masyarakat kecil untuk berperan di pasar modal.

\footnotetext{
43 M. Irsan Nasarudin dan Indra Surya, Op.Cit., 226.

Ibid.

45 Jaka E. Cahyono, Investing in JSX Now?No I'm Not That Fool Another "Strategi dan Kiat Meraih Untung di Bursa Saham” (Elex Media Komputindo 2002) 69.

46 Ridwan HR, Hukum Administrasi Negara (Raja Grafindo Perkasa 2008) 15.

47 Jum Anggriani, Op.Cit. 40.
} 
Sesungguhnya, bila memang dikehendaki, pasar modal dapat menyediakan peluang bagi pemodal kecil dengan berbagai cara, yaitu diantaranya: 48

a. Pasar modal memberi akses seluasluasnya bagi mikro Banking untuk dapat menerbitkan obligasi saham untuk ekspansi lebih banyak ke masyarakat.

b. Dengan menciptakan akses langsung maupun menciptakan skema produk yang bertarget kepada pemodal kecil.

Filosofi/Tujuan Pengaturan Pasar Modal Indonesia Ditinjau dari Pasal 33 UUD NRI 1945 Paska Amandemen

Pembangunan ekonomi di Indonesia tidak dapat dipisahkan dari falsafah yang melandasi kegiatan bernegara dan berbangsa, termasuk dalam kaitannya dengan perekonomian. ${ }^{49}$ Upaya untuk meningkatkan kesejahteraan rakyat dalam pembangunan ekonomi juga menjadi suatu bentuk untuk mewujudkan Indonesia menjadi negara kesejahteraan. Ciri utama negara kesejahteraan adalah pemerintah memiliki kewajiban untuk mewujudkan kesejahteraan umum bagi warganya. ${ }^{50}$ Konsepsi negara hukum untuk mencapai negara kesejahteraan di
Indonesia terkandung dalam alinea 4 Pembukaan UUD NRI 1945, yang tercermin dari tujuan negara Indonesia, yaitu memajukan kesejahteraan umum, mencerdaskan kehidupan bangsa, dan seluruh tumpah darah Indonesia serta ikut melaksanakan ketertiban dunia yang berdasar perdamaian abadi dan keadilan sosial. ${ }^{51}$

Prinsip perekonomian nasional adalah sebagai berikut: kebersamaan, efisiensi, berkeadilan, berkelanjutan, berwawasan lingkungan, kemandirian, serta menjaga keseimbangan kemajuan dan kesatuan ekonomi nasional. ${ }^{52}$ Asas kekeluargaan dan prinsip-prinsip tersebut tidak dapat dipisahkan dari Pancasila. Berdasarkan asas dan prinsip perekonomian nasional dapat dilihat relevansinya dalam sila ke-5 Pancasila yaitu keadilan sosial bagi seluruh rakyat Indonesia.

Dalam konteks ke-Indonesia-an, teori keadilan harus sesuai dengan kebenaran menurut sistem pemikiran bangsa Indonesia. ${ }^{53}$ Keadilan dalam sila ke-5 Pancasila mengandung makna adanya perlakuan adil baik dalam bidang politik, ekonomi maupun sosial budaya. ${ }^{54}$ Makna keadilan sosial, jika dilihat dari penjelasan rinci sila ke-5 Pancasila yaitu sebagai berikut: ${ }^{55}$

48 Ubaidillah Nugraha, Catatan Keuangan dan Pasar Modal: Buku Panduan Berinvestasi yang Memaparkan Secara Berimbang Manfaat, Resiko dan Kontroversi Dunia Keuangan Dan Pasar Modal (Elex Media Komputindo 2008) 9.

49 Lastuti Abubakar, Op.Cit., 41.

$50 \quad$ Ridwan HR, Op.Cit., 15.

51 Jum Anggriani, Loc.Cit.

52 Pasal 33 Ayat (4) Undang-Undang Dasar Negara Republik Indonesia Tahun 1945.

$53 \quad$ Ibid, 37.

54 Mustafa Kemal Pasha, DKK, Op.Cit., 199.

55 Teguh Prasetyo dan Abdulhakim Barakatullah, Filsafat, Teori, \& Ilmu Hukum: Pemikiran Menuju Masyarakat yang Berkeadilan \& Bermartabat (Raja Grafindo Persada 2012) 378. 
a. Mengembangkan perbuatan luhur yang mencerminkan sikap dan suasana kekeluargaan serta kegotong royongan

b. Bersikap adil

c. Bersama-sama dalam usaha mewujudkan kemajuan yang merata dan berkeadilan sosial

Keadilan sosial juga dapat dimaknai bahwa $^{56}$ keadilan politik dan keadilan ekonomi ialah isi yang menjadi terasnya keadilan sosial yang mengindahkan perkembangan masyarakat dengan jaminan, supaya kesejahteran umum terlaksana. Keadilan sosial memberi perimbangan kepada kedudukan perseorangan dalam masyarakat dan negara. Dengan adanya keadilan sebagai sila kelima dari dasar filsafat negara kita, maka berarti bahwa di dalam negara, makmur dan "kesejahteraan umum" itu harus terjelma keadilan sosial bagi seluruh rakyat Indonesia.

Pasal 33 UUD NRI Tahun 1945 mengenal adanya prinsip kemandirian dalam pembangunan ekonomi. Prinsip kemandirian tersebut tidak dapat dipisahkan dari prinsip keadilan. Keadilan diperlukan untuk menjadi landasan untuk mewujudkan prinsip kebersamaan dan kekeluargaan dalam pasar modal. Keadilan memiliki makna yang luas. Dalam konteks ekonomi Indonesia, makna keadilan dan kemakmuran tidak dapat dilepaskan antara satu dengan lainnya. ${ }^{57}$
Landasan filosofis pengaturan pasar modal di Indonesia tidak lepas dari landasan filosofis yang mendasari kebijakan pembangunan nasional pada era pemerintahan pada saat UU Nomor 8 Tahun 1995 ini terbentuk, yaitu di era Orde Baru. UU Nomor 8 Tahun 1995 disusun untuk memberikan kepastian hukum dalam menunjang eksistensi pasar modal sebagai salah satu sumber pembiayaan bagi dunia usaha dan sebagai wahana investasi bagi masyarakat.

UUD NRI 1945 sebagai konstitusi Indonesia merupakan suatu bentuk haluan negara. ${ }^{58}$ Haluan negara diartikan sebagai policy (kebijakan) maupun arah pedoman bagi penyelenggaraan negara, dalam hal ini baik dalam bidang ekonomi, kebudayaan, maupun hukum. Sebagai salah satu bentuk kegiatan ekonomi, pasar modal Indonesia yang diadopsi dari sistim ekonomi kapitalis, diterapkan di Indonesia disesuaikan dengan apa yang diatur dalam UUD NRI 1945. Dalam bidang ekonomi Indonesia, pengaturan tentang pembangunan ekonomi di Indonesia dituangkan dalam Pasal 33 UUD NRI 1945 (Amandemen IV) sebagai landasan dalam penyelenggaraan ekonomi Indonesia. ${ }^{59}$

Dasar yang digunakan dalam pengaturan pasar modal juga mengacu pada dasar pembangunan ekonomi

56 Dewi Khayati, 'Teori Keadilan Sosial' <http://susantnext.blogspot.com/2012/03/teori-keadilansosial.html> diakses 4 September 2015.

57 Tulus Tambunan, 'Keadilan dalam Ekonomi'<http://id.pdfsb.com/readonline/ 5a6c42436667392f573356394333746d56413d3d> diakses 18 Mei 2013.

58 Jimly Asshiddiqie, Op.Cit., 17.

59 Lastuti Abubakar, Op.Cit. 41. 
Indonesia. Pasal 33 UUD NRI Tahun 1945 menjadi landasan konstitusional pasar modal sehingga pasar modal harus patuh pada asas kekeluargaan dalam Pasal 33 ayat (1) UUD NRI Tahun 1945 serta prinsip-prinsip perekonomian dalam Pasal 33 ayat (4) UUD NRI Tahun 1945.

Makna asas kekeluargaan merupakan suatu upaya dalam pasar modal yang dilaksanakan secara bersama oleh seluruh rakyat Indonesia, baik bagi pemerintah dan swasta, maupun bagi yang bergolongan penghasilan tinggi maupun golongan penghasilan rendah. Dalam praktiknya, pasar modal yang di dalamnya didukung oleh banyak pihak, seperti emiten, perantara pedagang efek, kustodian, wali amanat sebagian besar dilakukan oleh sektor swasta. Pemerintah memiliki bagian di dalamnya sebagai pembentuk aturan dalam pasar modal, selain itu pemerintah berada sebagai lembaga pengawas pasar modal (Bapepam dan LK), yang pada saat ini telah beralih kepada Otoritas Jasa Keuangan (OJK).

Seiring apa yang telah dijelaskan dalam Pasal 33 ayat (1) UUD NRI 1945, makna yang sama juga ada dalam Pasal 33 ayat (4) UUD NRI Tahun 1945. Pasal tersebut menyatakan bahwa penyelenggaraan perekonomian berdasarkan asas demokrasi ekonomi dengan berbagai macam prinsip, salah satunya adalah prinsip kebersamaan. Makna atas prinsip kebersamaan tersebut memiliki makna yang hampir sama dengan makna kekeluargaan yang tertuang dalam ayat (1). Makna kebersamaan dalam ayat (4) dalam harus dilihat ke dalam makna yang lebih luas. Harus disadari bahwa dalam dalam mewujudkan pembangunan ekonomi Indonesia pemerintah memiliki keterbatasan, baik dalam hal dana maupun daya. Oleh sebab itu, berdasarkan prinsip kebersamaan tersebut tanggung jawab atas pembangunan nasional harus dilaksanakan bersama-sama oleh pemerintah dan masyarakat. ${ }^{60}$

Prinsip kebersamaan dan kekeluargaan dalam bidang pasar modal dapat terpenuhi dengan adanya ketersediaan sarana investasi yang diberikan bagi mereka yang bukan berasal dari golongan yang bermodal besar. Dalam penjelasan UU No. 8 Tahun 1995 bagian umum dieksplisitkan bahwa pasar modal memiliki peran dalam menunjang pembangunan nasional sebagai salah satu sumber pembiayaan bagi dunia usaha baik usaha menengah kecil dan mikro (UMKM), dan di sisi lain merupakan wahana investasi masyarakat termasuk dalam hal ini pemodal kecil dan menengah.

Merujuk kembali pada tujuan pengaturan pasar modal dalam konsideran huruf $\mathrm{b}$ dijelaskan bahwa pasar modal merupakan sumber pembiayaan bagi dunia usaha. Dengan tujuan tersebut, pasar modal diharapkan mampu dan memberikan wadah dalam melakukan pembiayaan bagi kegiatan usaha apapun di Indonesia

60 Jonker Sihombing, Op.Cit. 75. 
termasuk dalam hal ini adalah koperasi dan UMKM. Namun, tampaknya belum ada pengaturan dalam pengaturan pasar modal yang dapat mewadahi koperasi dan UMKM untuk turut ambil bagian di dalamnya. Jadi, jika dilihat dalam pengaturan pasar modal, yang dikaitkan dengan Pasal 33 Ayat (1) UUD NRI 1945, maka pasar modal belum sepenuhnya memenuhi tujuan pengaturannya karena belum dapat menjadi sumber pembiayaan dalam seluruh bidang usaha.

\section{PENUTUP}

Berdasarkan pembahasan yang telah diuraikan di atas diperoleh simpulan sebagai berikut:

1. Tujuan pengembangan pasar modal Indonesia memiliki perbedaan dengan tujuan pasar modal di negara-negara yang menganut sistem ekonomi kapitalistik. Perbedaan tersebut terlihat bahwa tujuan pengembangan pasar modal Indonesia adalah mewujudkan masyarakat Indonesia yang adil dan makmur.

2. Tujuan pengaturan pasar modal Indonesia belum sepenuhnya bersesuaian dengan konsep Negara Kesejahteraan Indonesia, khususnya dari segi akses keadilan bagi pemodal kecil untuk berpartisipasi di pasar modal.

3. Filosofi/tujuan pengaturan pasar modal Indonesia ditinjau dari Pasal 33 UUD NRI 1945 Pasca Amandemen belum sepenuhnya mampu memenuhi apa yang diharapkan dalam Pasal 33 UUD NRI 1945 khususnya adalah dalam kaitannya dengan keterkaitan koperasi dan UMKM dalam pasar modal.

\section{DAFTAR BACAAN}

\section{Buku-Buku}

Abubakar, Lastuti, Transaksi Derivatif Di Indonesia: Tinjauan Hukum Tentang Perdagangan Derivatif Di Bursa Efek (Book Terrace \& Library 2009).

Anggaraiani, Jum, Hukum Administrasi Negara (Graha Ilmu 2012).

Anwar, Jusuf, Pasar Modal Sebagai Sarana Pembiayaan dan Investasi (Alumni 2010).

Anwar, Jusuf, Penegakan Hukum dan Pengawasan Pasar Modal Indonesia, (PT Alumni 2008).

Asshiddiqie, Jimly, Konstitusi Ekonomi (Kompas 2010).

Bertens, Kees, Pengantar Etika Bisnis (Kanisius 2000).

Cahyono, Jaka E., Investing in JSX Now?No I'm Not That Fool Another "Strategi dan Kiat Meraih Untung di Bursa Saham" (Elex Media Komputindo 2002).

HR, Ridwan, Hukum Administrasi Negara (Grafindo Raja Persada 2008).

Nasarudin, M. Irsan, Aspek Hukum Pasar Modal Indonesia (Kencana 2004). 
Nugraha, Ubaidillah, Catatan Keuangan dan Pasar Modal: Buku Panduan Berinvestasi yang Memaparkan Secara Berimbang Manfaat, Resiko dan Kontroversi Dunia Keuangan Dan Pasar Modal (Elex Media Komputindo 2008).

Prasetyo, Teguh dan Abdulhakim Barakatullah, Filsafat, Teori, \& Ilmu Hukum: Pemikiran Menuju Masyarakat yang Berkeadilan \& Bermartabat (Raja Grafindo Persada 2012).

Sihombing, Jonker, Peran dan Aspek Hukum dalam pembangunan Ekonomi (PT Alumni 2010).

Sulastomo, Kapita Selekta: The Indonesian Dream (Kompas 2008).

Tambunan, Tulus, Keadilan Dalam Ekonomi (Kadin Indonesia-Jetro 2006).

Tanya, Benard L. Teori Hukum: Strategi Tertib Manusia Lintas Ruang dan Generasi (Genta Publishing 2010).

Tavinayati, dan Yulia Gamariyanti, Hukum Pasar Modal Indonesia (Sinar Grafika 2009).

\section{Artikel/Internet}

Bahar, Saafrodin, 'Bagaimana Melaksanakan Pancasila Sebagai Dasar Negara Melalui Paradigma Fungsional' (2007) Sekretariat Negara Republik Indonesia <http:// setneg.go.id> diakses 18 Mei 2013.

Khayati, Dewi, 'Teori Keadilan Sosial' <http://susantnext.blogspot.com/ $2012 / 03 /$ teori-keadilan - sosial.html> diakses 4 September 2015.

Piliyanti, Indah, 'Menggugat Sistem Kapitalisme' (2009) 3 Jurnal Ekonomi Islam.

Rahardjo, Dawam, 'Ekonomi Pancasila Dalam Tinjauan Filsafat Ilmu', $<\mathrm{h}$ t $\mathrm{t} \quad \mathrm{p}:$ / / www.ekonomikerakyatan.ugm.ac.id/ My\%20Web/sembul12_2.htm> diakses 18 Mei 2013.

Suharto, Edi, 'Globalisasi, Kapitalisme, dan Negara Kesejahteraan: Mengkaji Peran Negara Dalam Pembangunan Kesejahteraan Sosial di Indonesia' <http://www.policy.hu/suharto/ modul_a/makindo_08.htm > diakses 19 Mei 2012.

Tambunan, Tulus, 'Keadilan Dalam Ekonomi' <http://id.pdfsb.com/

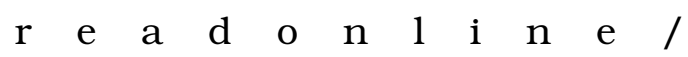
5a6c424366673925573356394333746d56413d3d> diakses 18 Mei 2013. 
